\title{
THE FEDERAL RESERVE'S MONETARY POLICY AND ITS EFFECTS (2008-2020): AN AUSTRIAN PERSPECTIVE
}

\author{
ANDRÉ MARQUES*
}

Fecha de recepción: 7 de enero de 2021

Fecha de aceptación: 27 de abril de 2021

\begin{abstract}
This paper aims to describe, according to the Austrian School of Economics, how the monetary policies adopted by the Federal Reserve since 2008 (Quantitative Easing - QE, Qualitative Easing - QL and Zero Percent Interest Rate Policy - ZIRP) prolonged the mismatches in resource allocation, made the US economy weaker (individuals and companies became more dependent on artificially low interest rates) and increased the risks and leverage in the financial market. It is argued that, after the adoption of these policies, the Fed would not be able to normalize monetary policy, which was confirmed in 2019, when the Fed began to cut the Federal Funds Rate (FFR) and did QE, and, mainly, in 2020, when it returned to ZIRP and did a bigger QE. It is concluded, therefore, that the Fed makes the economy weaker and increases the financial market's leverage. The real economy is harmed, while the financial market (large publicly traded companies and financial institutions) and the government (which increases its spending and indebtedness) are benefited.
\end{abstract}

Keywords: Austrian School of Economics, United States, Central Banks, Federal Reserve, Monetary Policy, Economic Cycles.

*André Marques, Brazilian (Recife-PE), holds a graduate degree in Political Science and International Relations at Universidade Nova de Lisboa and a master's degree in International Economics and European Studies at Universidade de Lisboa (ISEG). The author's e-mail address is andre.m.7@hotmail.com and his personal blog is https://theaustriancase.blogspot.com/. I would like to thank Philipp Bagus for suggesting me to write this article.

Disclaimer: This paper is an adaptation and a complement to the author's master's thesis in International Economics and European Studies at Universidade de Lisboa ISEG entitled "The Federal Reserve's Monetary Policy (2001-2019): An Austrian View", available at: https://www.iseg.ulisboa.pt/aquila/publico/listThesis.do?method=listThesisDetails\&thesisID=283407\&contentContextPath_PATH=/instituicao/ISEG/ topo/mestrados\&_request_checksum_=8bb58cd1d3757b7f7d6806deaf0277d 915076021 
JEL Classification: E14, E32, E43, E44, E52, E58, E62, H60.

Resumo: Este paper tem como objetivo descrever, segundo a Escola Austríaca de Economia, como as políticas monetárias adotadas pelo Federal Reserve a partir de 2008 (Quantitative Easing - QE, Qualitative Easing - QL e Zero Percent Interest Rate Policy - ZIRP) prolongaram os desajustes na alocação de recursos, enfraqueceram a economia americana (indivíduos e empresas tornaram-se mais dependentes de juros artificialmente baixos) e aumentaram os riscos e a alavancagem presentes no mercado financeiro. Argumenta-se que, após a adoção destas políticas, o Fed não seria capaz de normalizar a política monetária, o que se confirmou em 2019, quando Fed voltou a diminuir o FFR e a realizar $Q E$, e, sobretudo, em 2020, quando retornou ao ZIRP e aumentou o QE. Conclui-se, portanto, que o Fed enfraquece a economia e aumenta a alavancagem do mercado financeiro. A economia real é prejudicada em detrimento do mercado financeiro (grandes empresas de capital aberto e instituições financeiras) e do governo (que aumenta seus gastos e endividamento).

Palavras-Chave: Escola Austríaca de Economia, Estados Unidos, Bancos Centrais, Federal Reserve, Política Monetária, Ciclos Económicos.

Classificação JEL: E14, E32, E43, E44, E52, E58, E62, H60.

\section{I \\ INTRODUCTION}

This paper aims to describe, according to the Austrian School of Economics, how the Federal Reserve's (Fed) monetary policy adopted since 2008 (Quantitative Easing - QE, Qualitative Easing $\mathrm{QL}$ and Zero Percent Interest Rate Policy - ZIRP) contributed to increase the mismatches in the allocation of resources, as well as the risks and weaknesses of the financial system, in addition to making the economy weaker (more dependent on artificially low interest rates).

According to the Austrian Business Cycle Theory (ABCT), as in Rothbard (1969), central bank's interventions in the interest rate cause a distortion in the perception of individuals' real rate of time preference, which provokes a misallocation of resources and 
malinvestments that eventually must be settled by a recession. As argued by Roque (2018), the US real estate bubble of the 2000's and the 2008 financial crisis were caused, mainly, by the Fed's interference. In 2001, it reduced the Federal Funds Rate - FFR (reaching 1\% in July 2003, remaining at this level until July 2004). Roque demonstrates that the raises in the FFR since 2004 signaled the malinvestments (especially in the real estate market), leading to a recession.

The lower FFR did not reflect the real rate of individuals' time preference and the investments were not sustainable. The recession occurred after the FFR reached $5.25 \%$, level that prevailed in the 1990s. The economy was already more fragile and could not bear higher interest rates.

The following sections are devoted to these changes in the Fed's monetary policy and their effects on the real economy and the financial market. Section II is dedicated to the main changes in the Fed's monetary policy (QE, QL and ZIRP) in the period 2008-2015. In addition, it is argued why it would not be possible to normalize monetary policy once these changes were made. Section III focuses on the effects of these policies on the real economy and on the financial market (in the 2015-2019 period), while also demonstrating that monetary policy, in fact, was not normalized (in 2019, the Fed cut the FFR and did QE). Section IV is dedicated to the year 2020, when the Fed did a bigger QE and returned to ZIRP. Finally, in Section $\mathrm{V}$, it is concluded that these changes in monetary policy increase and prolong the mismatches in the allocation of resources, make the economy weaker (companies and individuals are increasingly dependent on artificially low interest rates), and benefit the financial market and the government at the expense of the real economy.

II

THE MAIN CHANGES IN THE FEDERAL RESERVE'S MONETARY POLICY (2008-2015)

This section is dedicated to the main changes in the Federal Reserve's Monetary Policy since 2008: QE, QL and ZIRP. 


\section{Quantitative Easing (QE) and Qualitative Easing (QL)}

As of 2008, the Fed adopted a so-called unconventional monetary policy, Quantitative Easing (QE). The objective was to prevent the asset prices from falling (mainly federal debt securities and Mortgage-backed Securities - MBS's). In doing so, interest rates would be lower.

The QE's mechanism was as follows: The Fed expanded the monetary base (M0) and purchased these assets in possession of financial institutions. The Fed's balance sheet increased (its assets increased because of the securities' purchases; its liabilities, because of M0's expansion). Financial institutions, on the other hand, got more reserves (in addition to getting rid of high-risk assets), which increased their liquidity. Therefore, in the balance sheets of these institutions, there was only a change in the composition of their asset. The Fed did three QE's (QE 1: 2008, QE 2: 2010-2011, QE 3: 2012-2014). It is possible to observe that the Fed's balance sheet and M0 increased simultaneously during these periods, remaining relatively constant between November 2014 and October 2017, as in chart $\mathrm{n}^{\circ} 1$.

\section{CHART No 1 : FED’S BALANCE SHEET AND MONETARY BASE - (2007-2017)}

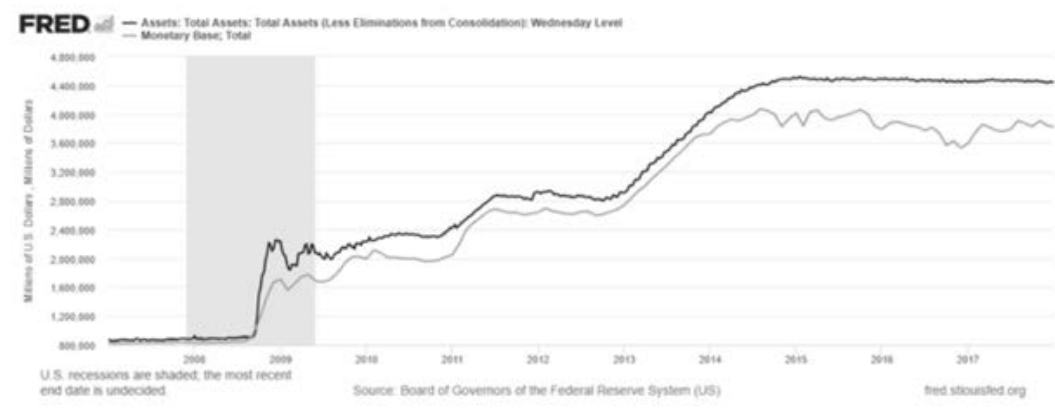

Fed's Balance Sheet (Black Line); Monetary Base (Grey Line).

Source: St. Louis Fed - Author's own Elaboration.

The Fed also did Qualitative Easing (QL), which, according to Bagus \& Schiml (2009), pp.46-49, corresponds not necessarily to an 
increase in the balance sheet, but to a change in its composition, deteriorating its quality. It is an exchange of higher quality assets (lower risk) for lower quality assets (higher risk). According to the authors, from the beginning of the crisis until September 2008, the Fed did not increase the size of its balance sheet. Instead, it reduced its quality by selling liquid federal bonds and buying lower quality assets (loans given to banks backed by illiquid assets), which can be considered a bailout of the banking system. This, as written by Bagus \& Schiml, also lowers the quality of the US dollar, since a central bank with lower quality assets has less capacity to defend the value of the currency when selling these assets for its currency. The authors also claim that a QE can be considered as a special case of QL if the assets purchased by the central bank reduce the average quality of its balance sheet, as occurred with the Fed's purchases of MBS's. In addition, according to Schlichter (2011) and Howden (2013), in 2011, the Fed sold T-Bills (short-term federal debt - up to one year) and bought long-term bonds (10 years), lowering their interest rates. This operation was called Operation Twist, as it changed the yield curve.

Normally, in conformity with Ulrich (2015b), the Fed's assets were mainly composed of T-Bills, and, therefore, less risky. However, the purchase of longer-term securities, through QE and Operation Twist, significantly changed the composition of the Fed's

\section{CHART N²: ASSETS IN THE FED'S BALANCE SHEET - (2005-2014)}

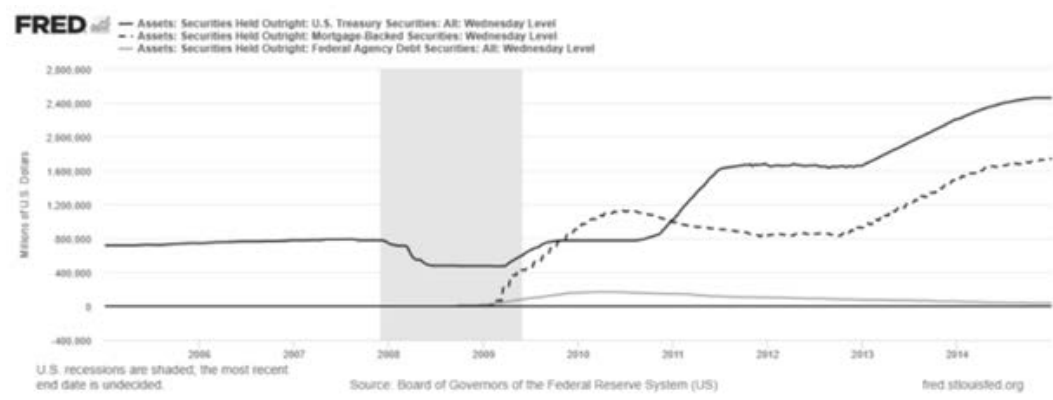

US Federal Debt: All Maturities (Black Line); Mortgage-backed Securities (Black Dashes); Federal Agency Debt Securities (Grey Line).

Source: St. Louis Fed - Author's own Elaboration. 
balance sheet, as it was composed by risker assets, such as MBS's (chart $\left.\mathrm{n}^{\circ} 2\right)$, and federal debt securities of longer terms (chart $\mathrm{n}^{\circ} 3$ ).

\section{CHART $N^{\circ}$ 3: COMPPOSITION OF THE US FEDERAL DEBT IN THE FED'S BALANCE SHEET - (2005-2014)}

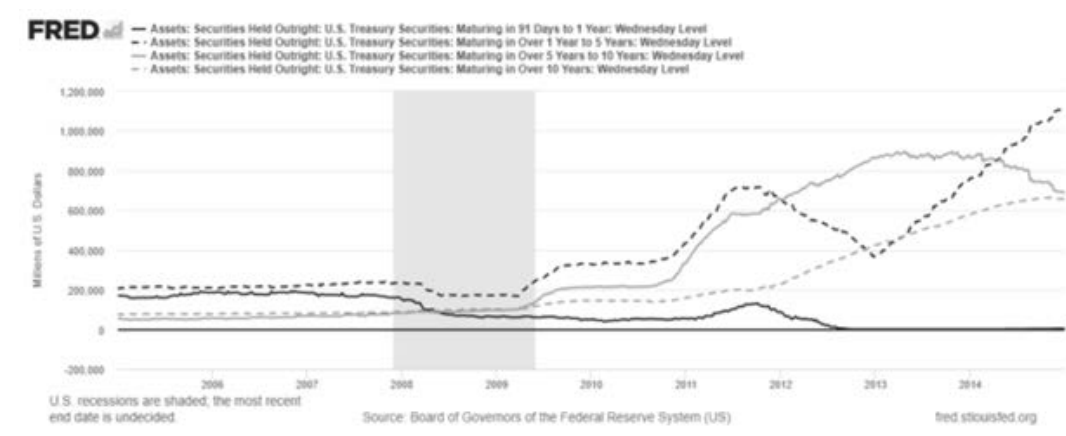

Bonds Maturing in 91 days to 1 year (Black Line); Bonds Maturing in 1 to 5 years (Black

Dashes); Bonds Maturing in 5 to 10 years (Grey Line); Bonds Maturing in over 10 years (Grey Dashes).

Source: St. Louis Fed - Author's own Elaboration.

An increase in the interest rate of these bonds would cause their prices to fall, which would mean losses in the event of a sale. According to Ulrich (2015b), this meant a potential complicating factor regarding the normalization of monetary policy, since if interest rates went up, the liquidity injected by the Fed could not be fully withdrawn, as the assets' value would be lower.

\section{ZIRP and the Change in the Way the Fed Influences the FFR}

In October 2008, the Fed changed the way it used to influence the FFR. Normally, the FOMC (Federal Open Market Committee) set a target for the FFR (the short-term interbank interest rate - 1 day) and the Fed bought and sold (expanding and contracting, respectively, the monetary base) short-term federal debt to commercial banks to cut or raise the FFR, respectively. This is a so-called 'Open 
Market Operation'. The FFR is the interest rate that banks use to lend money to each other and maintain the level of reserve requirements deposited with the Fed.

However, as mentioned in the article published by the Ludwig von Mises Institute Brazil - Instituto Mises Brasil (2016), due to the substantial increase in bank reserves caused by $\mathrm{QE}$, banks had excess reserves (that is, above the minimum level determined by reserve requirements), as shown in chart $\mathrm{n}^{\circ} 4$, and no longer needed to lend money to each other to maintain this level. As a result, the FFR fell to a level close to $0 \%$ (chart $n^{\circ} 5$ ).

Thus, as mentioned by Instituto Mises Brasil (2016), the Fed could no longer control the FFR through the previous monetary policy. Thus, it established a range for the FFR between $0 \%$ and $0.25 \%$, and it began to pay an interest rate to banks so that they would leave their reserves deposited with the Fed. This rate was called Interest Rate on Excess Reserves (IOER). The Fed kept it at around 0\% for about eight years (as in chart n ${ }^{\circ}$ ). This was the so-called ZIRP (Zero Percent Interest Rate Policy). As argued by Instituto Mises Brasil (2016), by paying interest to banks so that they leave their reserves at the Fed, it was able to influence the interbank interest rate, as the higher the IOER, the higher the interbank interest rate (FFR) would have to be in order to offset the opportunity cost of simply leaving reserves deposited with the Fed, earning interest. The FFR, therefore, started to move similarly to the IOER, as in chart $\mathrm{n}^{\circ} 5$.

According to Ulrich (2015a), the Fed also resorted to other instruments to influence the FFR (the Reverse Repurchase Agreement - RRP) and to manage the volume of reserves held by financial institutions (the Term Deposit Facility - TDF). The RRP, as described by Ulrich, is a credit line in overnight deposits at fixed rates through which the Fed borrows money using bonds in its balance sheet as collateral, promising to repurchase them at a future date. This tool is a supplement to the IOER as it covers a wider range of financial institutions, such as GSEs (Government-Sponsored Enterprises) - which includes Fannie Mae and Freddie Mac - and money market funds. The TDF operations, Ulrich demonstrates, are time deposits allocated by the Fed, removed from the banks' reserve balance during the term of the deposit. Through this facility, the Fed has a certain control over 
CHART N4: EXCESS RESERVES DEPOSITED WITH THE FED (1984-2019)

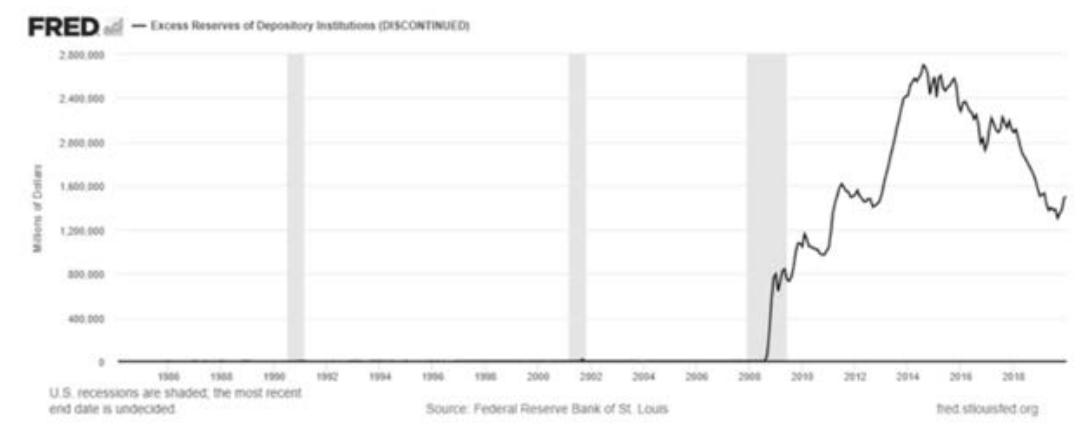

Source: St. Louis Fed - Author's own Elaboration.

CHART N 5: IOER AND FFR - (2008-2015)

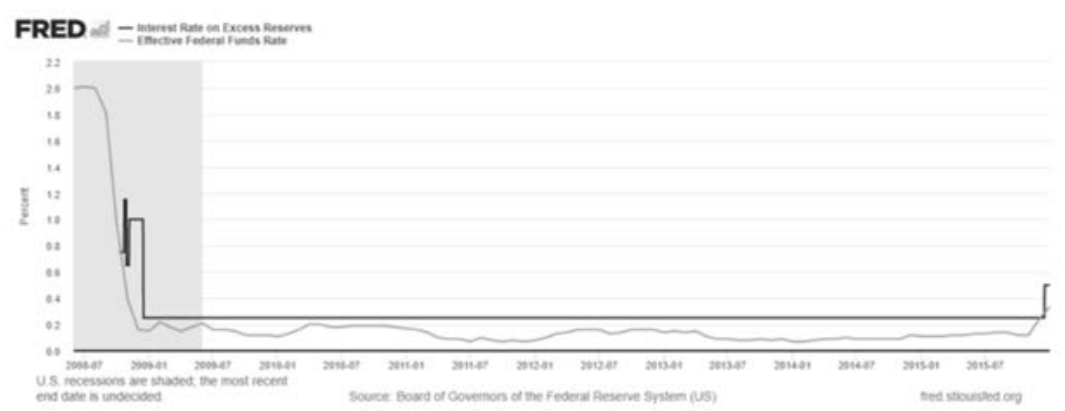

IOER (Black Line); FFR (Grey Line).

Source: St. Louis Fed - Author's own Elaboration.

these reserves, but it does not reduce them, as it is only an accounting record (credit to its term deposit account and debit to the reserve balance). The volume of bank reserves deposited with the Fed is not reduced, but rather it is raised, due to the remuneration paid to the banks. The oscillations of the Monetary Base observed in chart $\mathrm{n}^{\circ} 1$ are the result of the TDF operations.

According to Instituto Mises Brasil (2016), the IOER also increases the federal budget deficit. Legally, the Fed must pass its 
profits (excluding its operating expenses) to the Treasury. The IOER's interest comes from the Fed's operating profits, that is, it is taken from its equity and passed on to its liabilities (banks' reserves). Thus, the higher is the IOER, the lower are the Fed's profits, and the lower is the amount passed on to the Treasury, which puts pressure on the federal budget deficit.

In addition, as argued by North (2015), QE did not cause a significant increase in price inflation, as this new money supply remains in banks' excess reserves and the banking system keeps it deposited with the Fed, earning interest through the IOER. The Fed has direct control over M0 (which increases when the Fed does $\mathrm{QE})$, not over bank loans. The money supply created by $\mathrm{QE}$ did not enter the economy directly. Thus, according to Alden (2020), QE, by itself, does not cause generalized price inflation; it is just a recapitalization of banks. The authoress affirms that, if QE is simultaneous, for example, to a great fiscal deficit (with the Fed purchasing, from the banks, the new bonds issued by the Treasury), it generates more bank deposits (significantly increasing M2), which can contribute to a higher price inflation (depending on the intensity of deflationary factors).

The monetary inflation produced by these three QE's, therefore, did not cause a significant increase in the CPI (Consumer Price Index), but rather in real estate and financial assets prices, such as federal debt securities (higher prices and lower interest rates), stocks and corporate bonds - which will be covered in Section III.

\section{The Impossibility Monetary Policy Normalization}

Due to these changes in monetary policy, it would not be possible to normalize it without generating a recession, both in the sense of returning to a FFR between 5\% and 6\% (as in the 1990s), and in the sense of the Fed influencing the FFR through Open Market Operations. As explained by the ABCT, malinvestments caused by distortions in the interest rate must be settled, which creates a recession. And the more the arrangement prevails, the greater the economy's vulnerability to interest rates. 
As mentioned by Instituto Mises Brasil (2016), in order for the Fed to return to the traditional monetary policy, it would have to remove much of the excess reserves, which would mean a substantial sale of bonds to banks. If the Fed did this, the prices of these bonds would fall, and their interest rate would rise, which would adversely affect the US economy.

As it was doing QE, the Fed promised to normalize the FFR and sell the assets it purchased, once the economy recovered, as mentioned by Schiff Gold (2019c). This, therefore, would be the Quantitative Tightening (QT). However, this sale would cause both bank reserves and asset prices to drop (with the consequent rise in interest rates). And, as the economy would be more fragile, it would not be able to bear higher interest rates (even if below 5.25\%, the level that the FFR reached in 2006).

III

THE EFFECTS OF QE, QL AND ZIRP (2015-2019)

These unconventional monetary policies (QE, QL and ZIRP) have made the economy weaker and more dependent on artificially low interest rates. In addition, the Fed has failed to normalize monetary policy.

\section{The Real Economy is Damaged}

QE, QL and ZIRP did not benefit the real economy, but rather the federal government (with the appreciation of its bonds and falling interest rates) and financial institutions, whose balance sheets were freed from low quality assets.

According to Roque (2018), these policies adopted by the Fed resulted in a subsidy for the banking system: it collected its profits, and its losses were socialized. Thus, Wall Street banks operate at almost no risks (they make mortgage loans, sell MBS's to the Fed, get the amount back plus profits and deposit it with the Fed itself, which pays interest on these deposits).

Large publicly traded companies were benefited as well, as low interest rates increase the present value of their future earnings, 
which appreciates their shares. And, as mentioned by Schiff Gold (2020a), these companies were able to increase their indebtedness to reacquire their shares, which also appreciates them. In other words, the appreciation of stocks not necessarily meant solid fundamentalist indicators. These companies were heavily indebted, but they did not redirect resources to capital goods in order to increase productivity.

In addition, according to Lacalle (2017), the arrangement enabled by QE and ZIRP caused an increase in the number of Zombie Companies - companies over 10 years old that have an EBIT (Earnings Before Interest and Taxes)/interest expenses ratio lower than 1. So, despite low interest rates, they are not able to bear the interest on their debt (as well as the principal) with their operating profits. They continue to operate with debt refinancing (debt issuances to pay past debts). Therefore, Lacalle argues, the maintenance of these companies is detrimental to the real economy (with more fragile companies) and to citizens (with lower real wages). It is a transfer of wealth from savers and financially healthy companies to inefficient companies. The author states that this creates a moral hazard: productive companies are, in a way, taxed; the non-productive, benefited. This incentive, adds Lacalle, does not protect jobs in the medium and long term, since credit for productive companies falls as zombie companies' indebtedness rises. If artificially low interest rates started to rise, zombie companies would fail, and the productive ones would not be able to limit the impact as they had lower access to credit to increase their productivity over the years.

\section{Monetary Policy was not Normalized}

The Fed raised the FFR for the first time in December 2015, gradually raising it again as of December 2016 (chart no6). Until December 2018, the Fed maintained the narrative of normalizing monetary policy, raising the FFR and doing QT.

However, in December 2018, when the FFR was nearly at 2.5\%, there was a significant drop in financial assets, as pointed by Maharrey (2020a). As of that month, the Fed announced it would not raise rates throughout 2019 and it cut the FFR three times (July, 
CHART N 6: IOER AND FFR - (2015-2019)

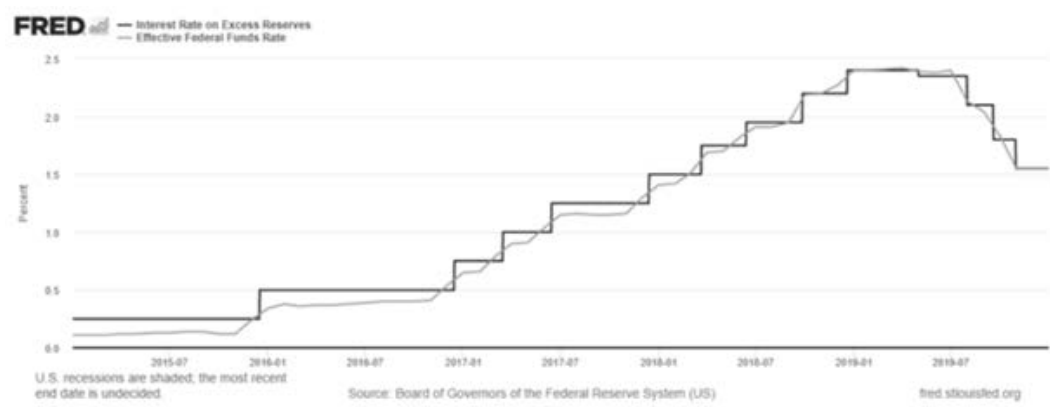

IOER (Black Line); FFR (Grey Line).

Source: St. Louis Fed - Author's Own Elaboration.

September, and October 2019) - chart n ${ }^{\circ} 6$. And, as of October 2017, the Fed started to reduce its balance sheet, slowly doing QT. The decrease was only from about US \$ 4.5 trillion in October 2017, to approximately US \$ 3.75 trillion in September 2019, as in chart $\mathrm{n}^{\circ} 7$.

\section{CHART N ${ }^{\circ}$ 7: FED'S BALANCE SHEET AND MONETARY BASE -} (2015-2019)

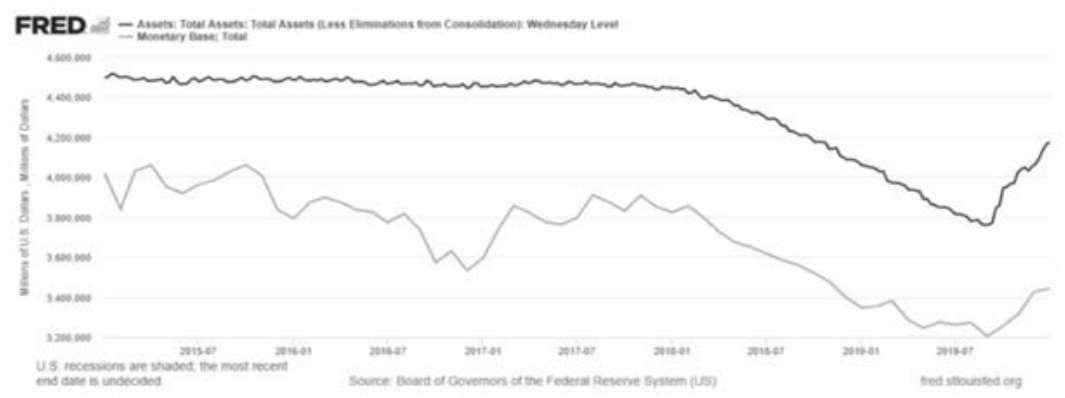

Fed's Balance Sheet (Black Line); Monetary Base (Grey Line).

Source: St. Louis Fed - Author's own Elaboration.

Therefore, in 2019 the Fed had already abandoned the narrative of normalizing monetary policy. However, as of September 2019, 
the change became more significant. As mentioned by Beltrão (2019), in the middle of that month there was an abrupt raise in the Overnight Repo Rate - or Repo Rate (Repo is an abbreviation for Repurchase Agreements), from 2\% to 10\%. The Fed, therefore, started to inject liquidity into this market. As described by Beltrão, this is the market that banks, investment funds, brokers and other financial institutions resort to for short-term loans. If a bank (or investment fund) needs funds to meet a short-term obligation and there is another institution that has available funds, the latter lends money to the former (which gives an asset as collateral; usually, a government bond). After the loan's term ends, the borrower repurchases the asset that was delivered to the lender.

One of the main reasons for this sudden shortage of funds in this market can be attributed to QT, as mentioned by Schiff Gold (2019a): the contraction of the Fed's balance sheet reduces bank reserves (banks use them to repurchase the assets that were held by the Fed), and these reserves are the main source of liquidity for the repo market.

According to Lacalle (2019b), this repo market crisis showed that there is a great leverage and lack of liquidity, even with a high level of excess reserves. Liquidity is substantially lower than what the Fed believes it is. For Lacalle, this crisis revealed that the risks and the accumulation of debt are much greater than estimated.

The financial market's weakness and low liquidity can also be verified through the banks' unrealized losses, in periods after the Fed starts to raise the FFR (which preceded past recessions, represented, in chart $n^{\circ} 8$, by the shady bars). An increase/decrease in the value of the assets that the bank has in its balance sheet represents an unrealized gain/loss (which would occur if the assets were sold). In order to convert unrealized losses into unrealized gains, the Fed, in addition to cutting the FFR, injects liquidity into the repo market (through its repurchase agreements), as occurred as of September 2019 and in other periods after the Fed raised the FFR - 1999-2001 and 2006-2008.

On October 8, 2019, the Fed announced it would do monthly purchases of $\$ 60$ billion of short-term federal debt at least until June 2020, which would result in a total of about $\$ 400$ billion added to the Fed's balance sheet, as mentioned in Schiff Gold (2019b). This 
CHART No 8: BANKS' NET UNREALIZED GAINS/LOSSES, FFR, REPURCHASE AGREEMENTS - (1998-2020)

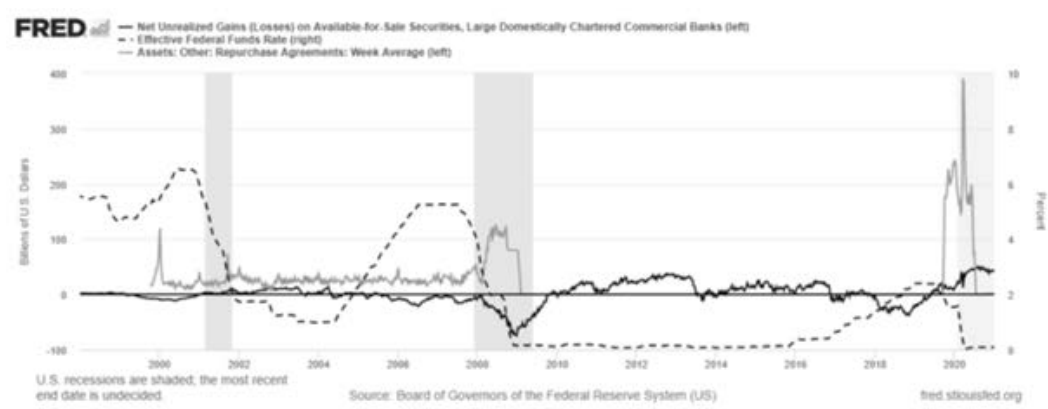

Banks' Net Unrealized Gains/Losses (Black Line, Left); FFR (Black Dashes, Right); Repurchase Agreements (Grey Line, Left).

Source: St. Louis Fed - Author's own Elaboration.

action can be considered a $\mathrm{QE}$. Like previous QE's, it makes the interest rate artificially lower (increasing bond prices), it increases the size of the Fed's balance sheet and it keeps financial asset prices artificially high, as stated in Schiff Gold (2019b).

The economy's fragility reflected in this reversal of the Fed's actions in 2019 is pointed out by Lacalle (2019a), who mentions that the Fed stated that the economy was growing at a good pace, that the unemployment rate was at its lowest level in 50 years and that the CPI was above the limit set by the Fed (which brings the need to raise the FFR). However, as argued by Lacalle, the Fed also stated that it was necessary to cut the FFR and to expand its balance sheet. Both statements were not compatible, says Lacalle, and the reason could be related to the need to maintain an excessively leveraged financial market and to prevent financial asset prices from falling.

These monetary policies adopted by the Fed, therefore, prevented an interest rate rise and a devaluation of financial assets, both in 2008-2012 and in 2018-2019. The government, companies, and individuals, therefore, continued to increase indebtedness, as in charts $n^{\circ} 9$ and $n^{\circ} 10$. Indebtedness increased as the Fed cut the FFR. 
CHART N 9: FFR AND US FEDERAL DEBT ${ }^{1}$ - (1970-2019)

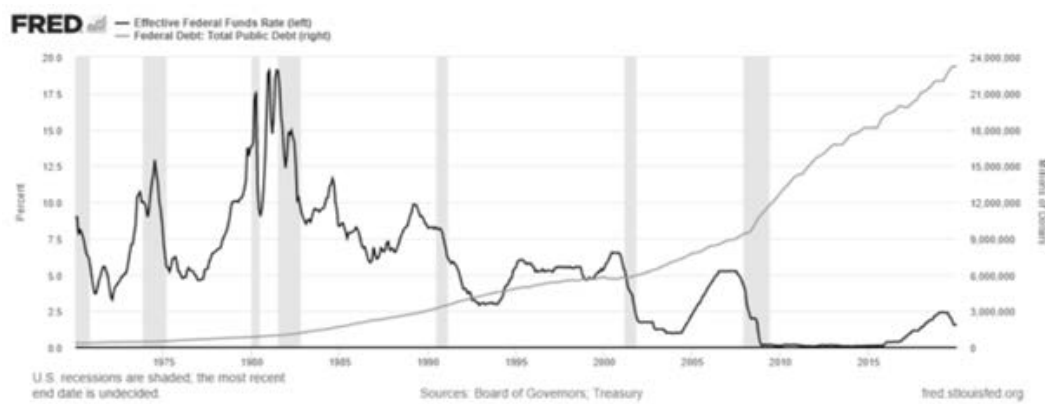

FFR (Black Line, Left); US Federal Debt (Grey Line, Right).

Source: St. Louis Fed - Author's own Elaboration.

\section{CHART N ${ }^{\circ}$ 10: CONSUMER CREDIT ${ }^{2}$, CORPORATE DEBT, STUDENT LOANS, MORTGAGE DEBT - (1970-2019)}

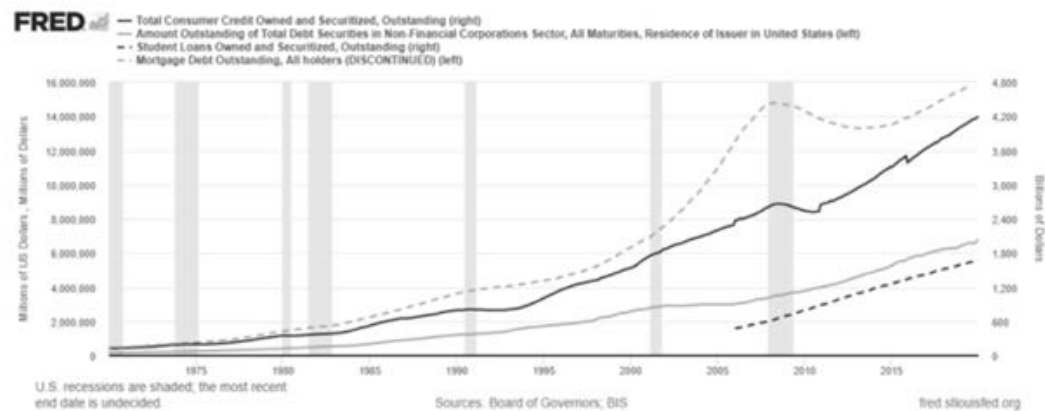

Consumer credit (Black Line, Right); Corporate Debt (Grey Line, Left); Student Loans (Black Dashes, Right); Mortgage Debt (Grey Dashes, Left).

Source: St. Louis Fed - Author's own Elaboration.

The bigger economy's vulnerability to interest rates can also be verified in chart $n^{\circ}$ 9. In 1980, Paul Volcker, Fed chairman at the time, raised the FFR to about $17.6 \%$. In 1981, he raised it to $19.1 \%$.

${ }^{1}$ It does not include unfunded liabilities (such as social security, medicare and medicaid), contingent liabilities (such as student loans), state debt, and local debt.

${ }^{2}$ It includes credit card debt, student loans and auto loans. It does not factor in mortgage debt. 
Both increases were accompanied by a recession. As the decades passed by, however, the level of FFR elevation that the economy was able to bear without suffering a recession became smaller.

\section{0: THE FED RETURNS TO ZIRP AND INCREASES QE}

In 2019, therefore, the Fed was already on its way back to ZIRP and doing $\mathrm{QE}$. The economy and the financial market were already showing signs of weakness. The Fed was going to keep cutting the FFR and, at least, keeping the QE's pace. However, in March 2020, after the announcements of lockdowns around the globe and the respective expected losses of corporate revenues, the reversal of the Fed's monetary policy observed since December 2018 was accelerated.

This section is dedicated to the Fed's return to ZIRP and the increase in $\mathrm{QE}$, as well as the differences from previous QE's.

\section{The Return to ZIRP and the Increase in QE}

In early March, the Fed cut the FFR from $1.6 \%$ to $1.1 \%$ (chart $\mathrm{n}^{\circ} 12$ ). On March 11, the US economy officially entered a bear market,

CHART N 11: DOW JONES, S\&P 500, NASDAQ - (2018-2020)

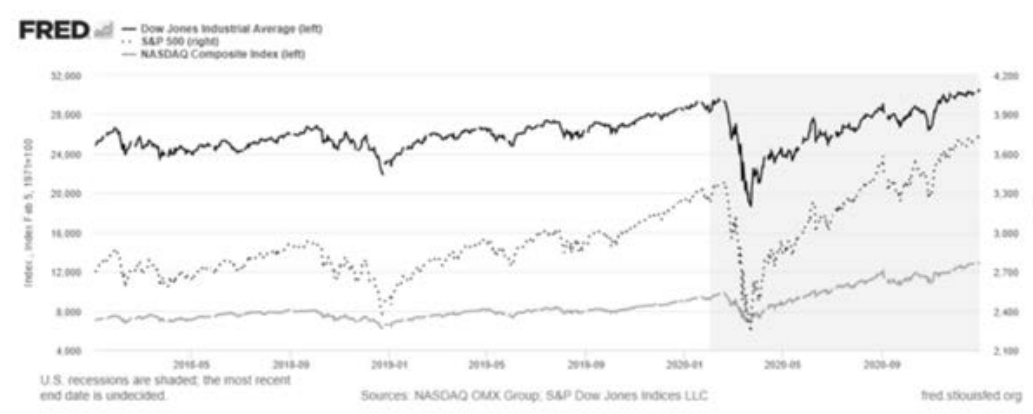

Dow Jones (Black Line, Left); S\&P 500 (Black Dots, Right); NASDAQ (Grey Line, Left). Source: St. Louis Fed - Author's own Elaboration. 
with the Dow Jones registering a 20\% drop. The S\&P 500 recorded more than a 20\% drop from the top reached in February. NASDAQ also suffered a significant drop, as in chart $n^{\circ} 11$.

Thus, on March 15, the Fed cut the FFR from 1.1\% to $0.1 \%$ (chart $\left.\mathrm{n}^{\circ} 12\right)$. In addition, the Fed increased its repurchase agreements operations (which it was doing since September 2019) when the unrealized gains of commercial banks began to drop, as in chart $n^{\circ} 13$.

CHART Nº 12: IOER AND FFR - (2019-2020)

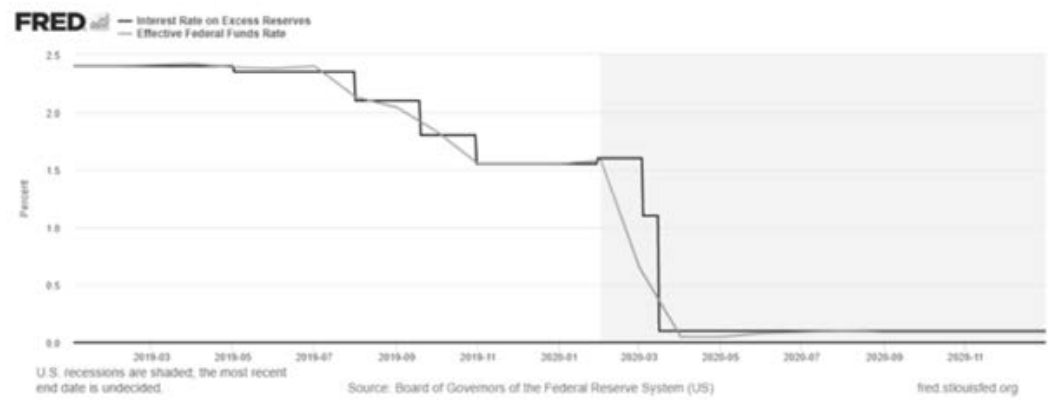

IOER (Black Line); FFR (Grey Line).

Source: St. Louis Fed - Author's own Elaboration.

CHART N ${ }^{\circ}$ 13: BANKS’ NET UNREALIZED GAINS/LOSSES, FFR, REPURCHASE AGREEMENTS - (2019-2020)

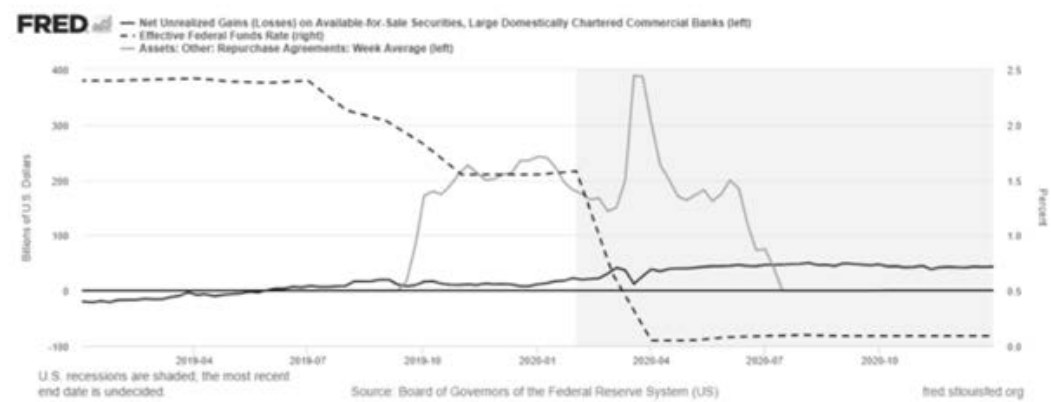

Banks' Net Unrealized Gains/Losses (Black Line, Left); FFR (Black Dashes, Right);

Repurchase Agreements (Grey Line, Left).

Source: St. Louis Fed - Author's own Elaboration. 
According to Mordasov (2020), in March, the federal government announced the CARES Act (Coronavirus Aid, Relief, and Economic Security Act), providing $\$ 2.2$ trillion of liquidity to companies in the form of loans, as well as checks to individuals up to $\$ 1200$, depending on their income. It was approved by the congress and signed by the president on March 27. As pointed by Mordasov, due to lockdowns, the unemployment rate rose to $4.4 \%$ at the end of March. In April, this indicator reached 14.7\%, with 23.1 million people losing their jobs.

This spending increase by the federal government was reflected in a larger budget deficit, which was largely covered by the Fed. As demonstrated by Maharrey (2020b), in March and in April, the Treasury issued about $\$ 1.56$ trillion of debt. During this period, the Fed purchased $\$ 1.56$ trillion of government bonds. In other words, the Fed monetized $100 \%$ of the US debt issued in those months. Thus, the QE in March and April 2020 was substantially higher than the one in 2019.

About $2 / 3$ of the US debt issued from January 2020 to October 2020 was purchased by the Fed and the US banking system. Foreign and domestic demand for US debt were not big enough to absorb the debt issued in 2020. The banking system, and, especially, the Fed, are the entities that keep the price of these bonds artificially high, and, consequently, artificially low interest rates.

The US federal debt, therefore, increased from about $\$ 23$ trillion in early 2020 to nearly $\$ 27$ trillion at the end of the third quarter, as in chart $\mathrm{n}^{\circ} 14$. 
CHART No 14: FFR AND US FEDERAL DEBT ${ }^{3}$ - (2019-2020)

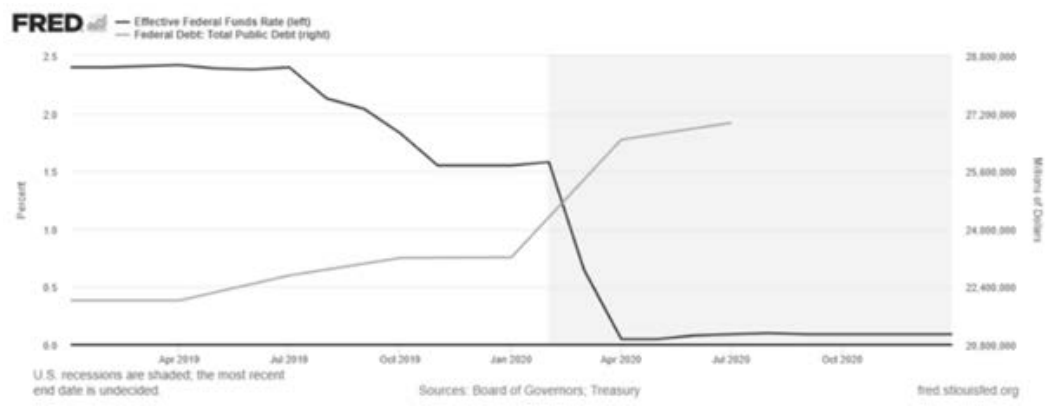

FFR (Black Line, Left); US National Debt (Grey Line, Right).

Source: St. Louis Fed - Author's own Elaboration.

In September 2020, the Fed announced that it would maintain the ZIRP until the CPI consistently rises and that it should let the CPI get just above the $2 \%$ target to maintain the ZIRP. In addition, some members of the FOMC projected the FFR being close to $0 \%$ until 2023.

Therefore, the economy has become more dependent on ZIRP and $\mathrm{QE}$ and it is less likely for the Fed to normalize monetary policy without causing a recession. ZIRP and QE, considered temporary (unconventional) measures when implemented in 2008, are now conventional monetary policies.

\section{Differences in Relation to Previous QE's}

The Fed's QE in 2020 differs from the previous ones in several ways, such as intensity (size of the balance sheet increase), types of assets (new classes of assets purchased by the Fed) and the impact on M2. This subsection is dedicated to these three differences and the impact of each one on the Fed's balance sheet.

\footnotetext{
${ }^{3}$ It does not include unfunded liabilities (such as social security, medicare and medicaid), contingent liabilities (such as student loans), state debt, and local debt.
} 


\subsection{The Increase in the Fed's Balance Sheet}

The huge budget deficit increase and the subsequent purchase of federal debt securities and other assets by the Fed resulted in a substantially bigger QE. The Fed's balance sheet got to $\$ 4.2$ trillion in early 2020, reaching nearly $\$ 7.2$ trillion in June, and remaining at this level until December, as in chart $\mathrm{n}^{\circ} 15$.

\section{CHART N ${ }^{\circ}$ 15: FED'S BALANCE SHEET AND MONETARY BASE - (JANUARY 2020-DECEMBER 2020)}

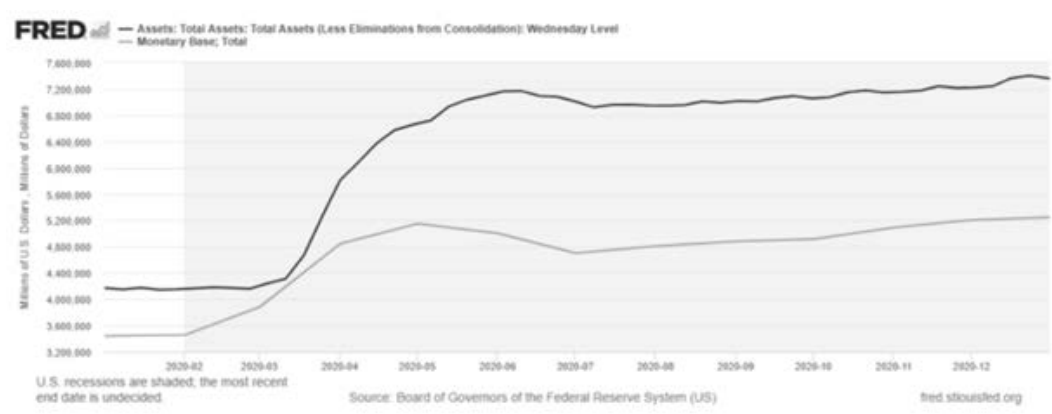

Fed's Balance Sheet (Black Line); Monetary Base (Grey Line).

Source: St. Louis Fed - Author's own Elaboration.

This substantial increase in the Fed's balance sheet and M0 decreases the quality of the US dollar, since, as mentioned by Bagus (2009b), pp.27-28, the currency's quantity is one of the factors that influences its quality, as it affects the currency's marginal utility by increasing the number of currency units. Additionally, since the Fed has increased its positions in lower quality assets, such as MBS's (chart $\left.n^{\circ} 16\right)$ and longer-term federal debt bonds (chart $n^{\circ} 17$ ), the 2020's QE is also a kind of QL, as it reduces the quality of the Fed's balance sheet. As stated by Bagus \& Schiml (2009), p.49, a QE can be classified as a special type of QL if the assets purchased by the central bank decrease the quality of its balance sheet. 
CHART No 16: ASSETS IN THE FED'S BALANCE SHEET - (2010-2020)

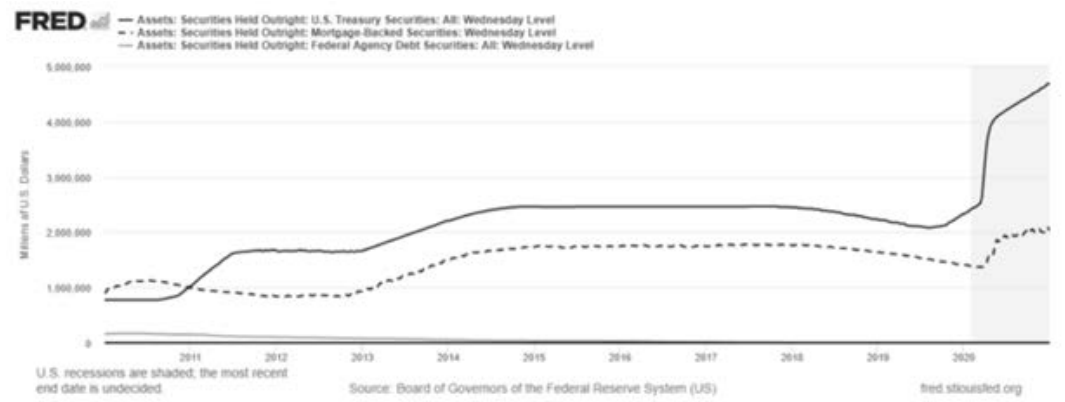

US Federal Debt: All Maturities (Black Line); Mortgage-backed Securities (Black Dashes); Federal Agency Debt Securities (Grey Line).

Source: St. Louis Fed - Author's own Elaboration.

\section{CHART N ${ }^{\circ}$ 17: COMPOSITION OF THE US FEDERAL DEBT IN THE FED'S BALANCE SHEET - (2010-2020)}

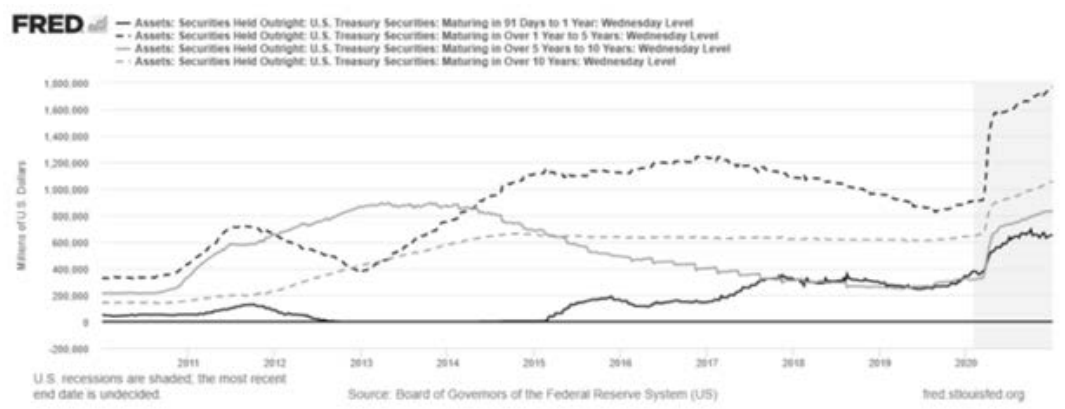

Bonds Maturing in 91 days to 1 year (Black Line); Bonds Maturing in 1 to 5 years (Black Dashes); Bonds Maturing in 5 to 10 years (Grey Line); Bonds Maturing in over 10 years (Grey Dashes).

Source: St. Louis Fed - Author's own Elaboration.

\subsection{New Types of Assets Purchased by the Fed}

The second difference refers to the so-called Secondary Market Corporate Credit Facility (SMCCF), included in the CARES Act. This time, the Fed purchased Exchange Traded Funds (ETF's) 
composed by corporate bonds. However, it was an indirect purchase. The Federal Reserve Act does not allow the Fed to purchase corporate bonds. Therefore, a Special Purpose Vehicle (SPV), an investment fund to which the Treasury provides capital and to which the Fed lends money, was stablished. In other words, the Fed does not directly buy any assets, it only lends money to the SPV (up to 10 times the amount invested by the Treasury).

According to Schiff Gold (2020b), as of June 19, the Fed already had $\$ 6.8$ billion in ETF's. And, in that same month, the Fed purchased $\$ 428$ million of individual bonds, of which $\$ 15.5$ million corresponded to junk bonds. The average maturity of these bonds was 3.3 years (ranging from 11 months to 5 years). Therefore, the Fed did not purchase long-term bonds.

The Fed's purchases of ETF's and individual bonds, in addition to increasing moral hazard, risk and fragility (greater dependence on artificially low interest rates and $\mathrm{QE}$ ), decrease the quality of the Fed's balance sheet, and, consequently, the quality of the US dollar. The fact that the market does not absorb these bonds (at least at the current interest rate level) and that the Fed is the one that purchases them, reveals that these assets are risker than they seem to be, as they are backed by companies that depend on the arrangement created by the Fed (ZIRP and QE).

\subsection{Impact on $\mathrm{M} 2$}

The third difference refers to the substantial increase in M2 simultaneously with QE. As mentioned in section II, the first three QE's carried out by the Fed (2008-2014) only resulted in an increase in $\mathrm{M} 0$, not in the currency in circulation, as explained by North (2015). However, as argued by Alden (2020), if QE is simultaneous to a large fiscal deficit (with the Fed purchasing, from the banking system, the new bonds issued by the Treasury) there is a significant increase in M2. As of March 2020, M2 significantly increased along with $\mathrm{M} 0$ and the Fed's balance sheet, as in chart $\mathrm{n}^{\circ} 18$. 
CHART N ${ }^{\circ}$ 18: MONETARY BASE, M2, FED'S BALANCE SHEET (2008-2020)

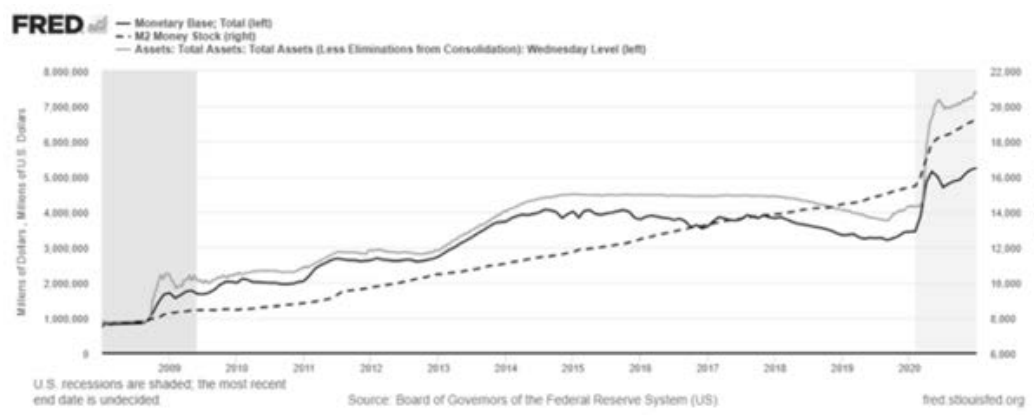

Monetary Base (Black Line, Left); M2 (Black Dashes, Right); Fed's Balance Sheet (Grey Line, Left).

Source: St. Louis Fed - Author's own Elaboration.

This rise of currency in circulation decreases the purchasing power of the US dollar and, thus, its quality. If the US dollar loses purchasing power, any asset denominated in it tends to lose value in real terms (compared to gold, for example). Therefore, the assets held by the Fed tend to worth less in real terms, and the quality of the Fed's balance sheet tends to be lower.

\section{$\mathrm{V}$ \\ CONCLUSION}

Based on the arguments of Austrian economists, it is possible to claim that QE, QL and ZIRP prolong the misalignments in resource allocation (also increasing the risk and intensity of a recession) and make the economy weaker, as dependency on artificially low interest rates on the part of the government (federal, state, and local), individuals and companies increases. The fragility of the financial market (which becomes more vulnerable to any liquidity crisis, such as that of repo operations in September 2019 , as the existing debt in the economy increases) is also intensified. In addition, productive (profitable) companies indirectly 
subsidize non-productive companies (zombie companies), as the later ones (due to the government and the Fed) have access to bailouts and artificially cheap credit, which wastes resources on unsustainable ventures. As this arrangement is prolonged, more productive companies become non-productive and more dependent on artificially low interest rates. Thus, the economy becomes less productive, with indebted and money-losing companies, as well as lower real wages).

Therefore, the Fed's monetary policy causes an appreciation of financial assets at the expense of the real economy. QE, QL and ZIRP stimulate both the bond and the stock market, but not sustainable investments and consumption. The more the Fed keeps the interest rate artificially low, the more financial assets prices can be appreciated (at least nominally). However, the economy becomes weaker. The Fed's monetary policy supports malinvestments, unproductive companies and prevents the growth of productive ones (as well as the emergence of new companies). This contrast between the financial and the real economy contributes to economic inequality, by inflating financial and real estate assets, which are held, in a greater volume, by higher income individuals. The Fed's monetary policy, therefore, does not favor the real economy, as it prevents further capital investment (higher productivity), which would lead to an increase in the quantity and quality of products and services, as well as jobs.

With the significant increase in QE and the return to ZIRP in 2020, the contrast between the real economy and the financial market has become more pronounced. Even with the huge increase in the unemployment rate over the months and the maintenance of lockdowns (which reduce corporate revenues, or eliminate them altogether, leading to bankruptcies), corporate bonds and the stock market appreciated. Publicly traded companies and financial institutions (Wall Street), as well as the government, were benefited, while small and medium-sized companies (the real economy, Main Street) suffered significant declines in their revenues or went bankrupt.

Publicly traded companies (even those that suffered revenue losses) were favored, as the Fed returned to ZIRP and increased QE (also purchasing corporate bonds). Financial institutions 
(commercial banks, investment funds and investment banks), once more, received a bailout through ZIRP and QE. And the government was able to increase its deficit to meet its spending increase.

\section{BIBLIOGRAPHICAL REFERENCES}

Alden, L. (2020): "Banks, QE, and Money-Printing," Available at: https://www.lynalden.com/money-printing/, 11/22/2020.

Bagus, P. \& Howden, D. (2009a): "Qualitative Easing in Support of a Tumbling Financial System: A Look at the Eurosystem's Recent Balance Sheet Policies," Economic Affairs, 29 (4), pp. 60-65. Available at: https://ssrn.com/abstract=1512878 or http://dx.doi. org/10.1111/j.1468-0270.2009.01948.x

- (2009b): “The Federal Reserve and the Eurosystem's Balance Sheet Policies During the Financial Crises: A Comparative Analysis," Romanian Economic and Business Review, 4 (3), pp. 165185.

- (2010): "The Term Structure of Savings, the Yield Curve, and Maturity Mismatching," The Quarterly Journal of Austrian Economics, 13 (3), pp. 64-85. Available at: https://mises.org/library/ term-structure-savings-yield-curve-and-maturity-mismatching

Bagus, P. \& Schiml, M. (2009): “New Modes of Monetary Policy: Qualitative Easing by the Fed," Economic Affairs, 29 (2), pp. 46-49. Available at: https://ssrn.com/abstract=1412908 or http://dx.doi. org/10.1111/j.1468-0270.2009.01893.x

Bagus, P. (2009a): “The Fed's Dilemma”. Available at: https://mises. org/library/feds-dilemma, 10/08/2009.

- (2009b): "The Quality of Money," The Quarterly Journal of Austrian Economics, 12 (4), pp. 22-45. Available at: https://mises.org/ library/quality-money

Beltrão, H. (2019): “Entrando Pelo Cano da Liquidez - O Congelamento Momentâneo do Mercado Repo Americano". Available at: https://mises.org.br/Article.aspx?id=3095, 09/26/2019.

Howden, D. (2013): "Who Benefits from the Fed?". Available at: https://mises.org/library/who-benefits-fed, 03/07/2013. 
Instituto Mises Brasil (2016): “Afinal, o Fed irá Elevar os Juros? Sua Decisão Refletirá sua Posição em Relação a Trump". Available at: https://www.mises.org.br/Article.aspx?id=2585, 12/12/2016. Lacalle, D. (2017): “The Rise of Zombie Companies — And Why It Matters". Available at: https://mises.org/library/rise-zombiecompanies---and-why-it-matters-0, 08/08/2017.

- (2019a): "Quantitative Easing Is Back". Available at: https:// www.dlacalle.com/en/quantitative-easing-is-back/, 10/09/2019.

- (2019b): "The Repo Crisis Shows the Damage Done by Central Bank Policies". Available at: https://mises.org/wire/repo-crisisshows-damage-done-central-bank-policies, 10/11/2019.

Maharrey, M. (2020a): "Extraordinary Federal Reserve Policy Began Over a Year Ago". Available at: https://schiffgold.com/ key-gold-news/extraordinary-federal-reserve-policy-began-over-a-year-ago/, 03/15/2020.

- (2020b): “Who Is Buying All This US Government Debt?". Available at: https://schiffgold.com/commentaries/who-is-buyingall-this-us-government-debt/, 06/17/2020.

Mordasov, P. (2020): “How Long Can the Fed Keep This Time Bomb from Exploding?". Available at: https://mises.org/wire/howlong-can-fed-keep-time-bomb-exploding, 10/21/2020.

North, G. (2015): "Ao Contrário do que diz a Imprensa, o Banco Central Americano não tem como 'Elevar os Juros'”. Available at: https://www.mises.org.br/Article.aspx?id=2213, 10/29/2015.

Roque, L. (2018): "Como Ocorreu a Crise Financeira Americana". Available at: https://www.mises.org.br/Article.aspx?id=1696, 08/17/2018.

Rothbard, M. (1969): Economic Depressions: Their Cause and Cure, Auburn, Alabama: Ludwig von Mises Institute [1st edition, 2009]. Available at: https://mises.org/library/economic-depressions-their-cause-and-cure-4

Schiff Gold (2019a): "Fed Runs Repo Operations; Is It Baby-Stepping Toward QE?". Available at: https://schiffgold.com/keygold-news / fed-runs-repo-operations-is-it-babystepping-toward-qe/, 09/18/2019.

- (2019b): "Fed Set to Launch "Massive" Bond-Buying Program In Other Words QE". Available at: https://schiffgold.com/key- 
gold-news / fed-set-to-launch-massive-bondbuying-program-in-other-words-qe/, 10/15/2019.

- (2019c): "Was Ben Bernanke Lying or Just Wildly Mistaken?". Available at: https://schiffgold.com/key-gold-news/was-benbernanke-lying-or-just-wildly-mistaken/, 02/21/2019.

- (2020a): "The Decade of Debt". Available at: https://schiffgold. com/key-gold-news/the-decade-of-debt/, 01/02/2020.

- (2020b): "Which Corporate Bonds the Fed Has Bought So Far?". Available at: https://schiffgold.com/key-gold-news/which-corporate-bonds-the-fed-has-bought-so-far/, 06/29/2020.

Schlichter, D. (2011): “Operation Twisted Logic". Available at: https://mises.org/library/operation-twisted-logic, 09/26/2011.

Ulrich, F. (2015a): “O que o Fed Poderá Fazer”. Available at: https:// www.mises.org.br/Article.aspx?id=2022, 01/30/2015.

- (2015b): “Qual é a Estratégia de Saída do Fed?". Available at: https://www.mises.org.br/Article.aspx?id=2019, 01/27/2015. 